\title{
Translating Anthropologies of Education
}

\section{KaTHRYN ANDERSON-LEVITT}

U MICHIGAN-DEARBORN

How does knowledge circulate, or fail to circulate, among academics across national and linguistic borders? This reflexive report takes the field of anthropology and education as a case in point.

Anthropology of education emerged as a distinct field in the United States in the 1950s and by 1970 had established an organization and a journal. It also appeared in Japan and Brazil about the same time, and since then many countries have seen the development of educational anthropology or of parallel approaches growing out of sociology, ethnology or folklore studies. Yet the flow of research findings across nations or language zones has been limited, with the US remaining particularly insular.

For example, anthropology of education took root over 50 years ago in Germany, where philosophical anthropology inspired an interest in Bildung, or education broadly defined as the formation of the person. By the early 1990s, the Commission on Educational Anthropology was active within the German Educational Research Association and has now sponsored a 12-year-long study of socialization through ritual and performance in families and classrooms in Berlin. Although some German anthropologists, such as Christoph Wulf of the Free University of Berlin, borrowed from US cultural anthropology-as well as from the Annales School-in shaping the field (Wulf in press), there has been little direct interaction between German and US scholars.

\section{Language Barrier}

The first barrier to interaction and free exchange of ideas is language; knowledge tends to circulate within speech communities that share a language or languages. The speech community of US academia seems to be fairly monolingual in English (with some exceptions, such as languages used in the field by anthropologists). Unfortunately, US scholars do not compensate by translating books into English; UNESCO's Index Translationum suggests that only a dribble of books get translated into English compared to the flood that get translated from English to other languages.

\section{Lost in Translation}

Languages encode cultural categories and assumptions that can be difficult to translate. The Dansk Pædagogiske Universitetsskole (DPU) or Danish School of Education, now affiliated with Aarhus University, provides a striking example. At DPU, a team of eight or more anthropologists working with colleagues in related disciplines have been offering a successful Danishlanguage program in Pcedagogisk antropologi and have been conducting rich research on childhood and youth and on learning in all kinds of Danish and overseas settings (Anderson et al, in press). Now that DPU is opening an English-language version of its program the group raised the question, at a workshop on November 26 on World Anthropologies of Education, of how to translate the program's title into English. The word pedagogy in English does not capture the connotations of building a person conveyed by the Danish, while the word education is too often interpreted as referring only to formal schooling. Even the label anthropology varies in meaning from one country to another. Moreover, in Danish, as in German, linguistic categories do not imply a divide between the humanities and the social sciences, as they do in English (Wierzbicka, in press).

\section{Defining Important Questions}

Beyond language differences and the cultural concepts they encode, distinct disciplinary traditions can hinder easy circulation. If scholars have been reading different sources and developing conversations along different lines in their journals, books and meetings, then they may come to see different problems as intellectually interesting. It is thus not only the language difference but also the distinct disciplinary trajectories growing out of philosophical anthropology in Germany and out of a highly empirical tradition in the US that explain the lack of contact between anthropologists of education in those two countries.

Perhaps most importantly, historical, social and political contexts shapes what scholars recognize as pressing problems, For example, the urgent concern of US scholars with educational inequity, particularly for minoritized students, is read in some countries with different histories as too lopsided an emphasis on school failure.

\section{Translatability}

The significance of research in educational anthropology fails to translate when we neglect to literally translate across languages, when cultural categories get lost in translation, when we fail to see one another's research as interesting because we have been engaged in different disciplinary conversations (which are constrained by the languages available), or when we miss the importance of one another's research because we frame it in a different historical, social or political context. "Translatability between languages of the social world" is possible and important but, as Peter Wagner writes, must be seen as "something [yet] to achieve" ("The twentieth century-the century of the

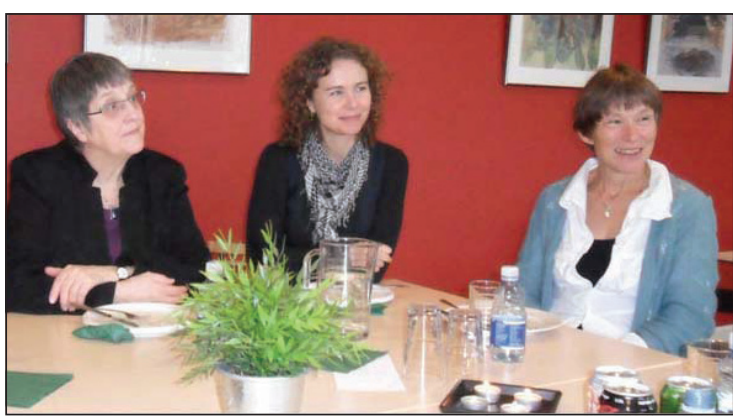

Sue Wright, Gritt Nielsen and Sally Anderson of the Danish School of Education at a workshop in Copenhagen on Worlds of Educational Anthropology, November 2010. Photo courtesy Kathryn Anderson-Levitt social sciences?" in World Social Science Report 1999). It requires efforts at each of these levels.

Kathryn Anderson-Levitt, professor of anthropology at the University of Michigan-Dearborn, served as editor of the Anthropology and Education Quarterly from 1994 to 2000. She has published Teaching Cultures (2002) and edited Local Meanings, Global Schooling (2003) and Anthropologies of Education (Berghahn, in press).

\section{Anthrosource}

A service of the American Anthropological Association

As a central membership benefit, AAA members enjoy

full access to AnthroSource, the premier online portal

serving the needs of educators, researchers, students

and practitioners. AnthroSource contains over 100 years

of anthropological research!

To learn more about AnthroSource, visit

www.aaanet.org/publications/anthrosource

AMERICAN

ANTHROPOLOGICA

ASSOCIATION

FOUNDED 1902

\section{WILEY-} BLACKWELL

\section{AnthroSource User Guides Available Online}

\section{Learn about the Basics}

Logging in and accessing full-text content

Advanced Features

TOC alerts and citation management

www.aaanet.org/publications/anthrosource/

AnthroSource-User-Information.cfm

Read them today. 